\section{Practical Application of the Provisions of the Code of Criminal Procedure Regarding the Measure of Preventive Arrest}

\section{Nicolae Silviu PANĂ', Ana Maria PANĂ²}

${ }^{1}$ Bachelor's degree from the University of Bucharest, Faculty of Law, master's degree from Nicolae Titulescu University, specialization in Business Law, lawyer in the Dambovita Bar, silviunpana@gmail.com

2 MA, Faculty of Law and Administrative Sciences, Valahia University of Targoviste, Romania, anappana17@gmail.com
Abstract Preventive measures are coercive criminal law enforcement institutions, aimed at the deprivation or restriction of individual liberty, by which the suspect or defendant is prevented from undertaking certain activities that would adversely affect the conduct of the criminal proceedings or the achievement of its purpose. They have been instituted by the legislator for specific purposes, namely: to ensure the proper conduct of criminal proceedings, to prevent the abstraction of the suspect or defendant from trial and to prevent the commission of new offenses (art. 202 para. 1 of the Criminal Procedure Code). Preventive measures are not inherent in any ongoing criminal trial, but are exceptional measures (art. 9 para. 2 of the Criminal Procedure Code), and the court can decide to sease the measure or make use of the measure in the light of the specific circumstances of each case. Of the five preventive measures, three are deprivation of liberty - detention, house arrest and pre-trial detention, and two are non-custodial: judicial control and judicial control on bail. All these measures are only applicable to the natural person. Specific preventive measures may be taken against legal persons, but those are regulated by the provisions of art. 493 of the Criminal Procedure Code.

Keywords: preventive measures, preventive arrest, deprivation of liberty.

How to cite: Pană, N. S., \& Pană, A. M. (2021). Practical Application of the Provisions of the Code of Criminal Procedure Regarding the Measure of Preventive Arrest. Logos Universality Mentality Education Novelty: Law, 9(1), 24-32. https://doi.org/10.18662/lumenlaw/9.1/53 


\section{Introduction}

The material jurisdiction to judge the proposal of the preventive arrest of the defendant against whom the criminal action was initiated for the crime of noncompliance with the weapons and ammunition regime, provided by art. 342 of the Penal Code, belongs to the judge of rights and freedoms within the criminal court, even if the criminal investigation was started in rem for the crime of forming an organized criminal group, provided by art. 367 of the Penal Code.

By the criminal conclusion no. 32 of November 1st, 2018 pronounced by the judge of rights and freedoms within the Gorj Tribunal in File no. $16269 / 318 / 2018$, the appeal of the prosecutor's office against the decision no. 35 of October 25th, 2018 pronounced by the judge of rights and freedoms from the Târgu Jiu Court in the case with the same number, regarding the respondents / defendants R.N.R. and G.V.D. was rejected.

This conclusion analysed, among other things, the preliminary issue of the competence of the judge of rights and freedoms within the Târgu Jiu Court to judge the proposal for pre-trial detention made by the Prosecutor's Office attached to the Gorj Tribunal against the defendants R.N.R. and G.V.D., accused of committing crimes of disturbing public order and tranquillity and non-compliance with the weapons and ammunition regime, provided by art. 371 of the Penal Code and art. 342 of the Penal Code.

Following the legality check performed (implicitly at the request of the defendants, formulated by the chosen defense counsel) by the judge of rights and freedoms from the superior court, it was ruled that the competence to settle the case belongs to the judge of rights and freedoms from Târgu Jiu Court.

In order to issue this judgment, the court held that the material jurisdiction (Barbu, 2016a, p. 234) was given by the distribution of criminal cases between the various courts, in relation to the nature or gravity of the offences which are the subject of those cases. Substantive jurisdiction is determined by the object of the criminal case, i.e. by the act committed and provided for by the criminal law, which caused the conflict of law which is the subject of the case brought before either the court or the judge of rights and freedoms (Barbu, 2019), as in the case of this particular situation.

As regards the substantive jurisdiction of the judge of rights and freedoms to resolve the pre-trial detention proposal which was the subject of the case, the court found that it was determined by reference to the offences for which the 
Practical Application of the Provisions of the Code of Criminal Procedure Regarding ... Nicolae Silviu PANĂ \& Ana Maria PANĂ

criminal action was initiated and not by the act for which it was ordered at the beginning of the in rem criminal investigation (Barbu, 2016b), respectively the crime of constituting an organized criminal group, provided by art. 367 of the Penal Code.

In the present case, the proposal for pre-trial detention concerns defendants against whom criminal proceedings have been instituted for the offence of disturbing public order and tranquillity and non-compliance with the arms and ammunition regime provided by art. 371 and art. 342 of the Penal Code, and the competence to judge these crimes in merits, according to art. 35 of the Criminal Procedure Code, belongs to the local court, and not to the county court.

It was also considered that the circumstance according to which the judge of rights and freedoms who solved the requests regarding the approval of searches or other evidentiary procedures during the criminal investigation regarding the offense provided by art. 367 of the Penal Code, according to art. 53 letter e of the Criminal Procedure Code will always resolve the pre-trial detention proposal, as, according to the legal provisions, this is not a criterion in determining the jurisdiction of the judge of rights and freedoms in resolving the pre-trial detention proposal.

On the other hand, the competence of the judge of rights and freedoms to resolve the requests regarding the approval of searches during the criminal investigation, or the use of special methods of supervision or investigation are determined by the initiation of a criminal investigation regarding the deed, as it results from the provisions of art. 140 et seq. of the Criminal Procedure Code, unlike the competence of the judge of rights and freedoms to resolve the proposal for pre-trial detention, when the competence is determined and established by the initiation of criminal proceedings regarding the commission of an offense by the defendant, according the provisions of art. 223 with reference to art. 82 of the Criminal Procedure Code.

Thus, the act that attracts the material jurisdiction is the ordinance to initiate the criminal action, considering that nothing prevents the prosecutor to investigate the other crimes too, such as the one provided by art. 367 of the Penal Code, or to establish the existence of one of the cases provided by art. 16 para. 1 of the Criminal Procedure Code (Barbu, 2016c).

In view of the above, in the case examined in the introduction of this article was assessed that, from the point of view of the material jurisdiction, the trial and settlement of the pre-trial detention proposal brought before the court belongs to the judge of rights and freedoms within the Târgu Jiu Court. 


\section{Establishing the material jurisdiction of the judge of rights and freedoms to judge the proposal for pre-trial detention}

The conclusion of the court, as cited above, brings into question the establishment of the material competence of the judge of rights and freedoms to judge the proposal of the preventive arrest of the defendant against whom the criminal action was initiated for an offence that is tried by the local court, but which begun as an in-rem investigation for an offence whose trial in under the jurisdiction of the county court.

Commenting on this case, we also agree with the arguments mentioned by the judge of rights and freedoms of the Gorj Tribunal, trying to argue and substantiate in more detail this jurisprudential opinion, given that at the praetorian level the opinion was held that in this situation the jurisdiction material belongs to the county court.

According to the latter opinion, the material jurisdiction to resolve the proposal of preventive arrest of the defendant belongs to the county court, because the provisions of art. 224 para. 2 of the Criminal Procedure Code are applicable. These provisions refer to "the court which would have jurisdiction to adjudicate the case in merits", in terms of all the crimes that are brought before the court during the same trial.

It is not in any way justified to make a distinction between the different interpretations given to the same phrase based on art. 224 para. 2, art. 140 para. 1 and art. 158 para. 1 of the Criminal Procedure Code. It is obvious, from the various legal provisions regarding the acts and the procedural measures that are made during the prosecution phase, that the legislator, by referring to the notion of "the court which would have jurisdiction to judge the case in merits", took into account the establishment of the jurisdiction of the court, according to the rules of criminal procedure governing territorial and material jurisdiction, or the jurisdiction pertaining to the quality of the person. The jurisdiction of the court cannot depend on the distinct conditions provided by the legislator for taking certain measures (initiation of criminal prosecution, in some cases, initiation of criminal proceedings, in other cases), with regard to one of the facts that are the object of the criminal investigation (the offence provided by art. 367 of the Criminal Code). Because this has no relevance in determining the jurisdiction of the court who is to rule on the merits of the case, consequently, it means that it has no relevance in determining the jurisdiction of the judge of rights and freedoms. 
Practical Application of the Provisions of the Code of Criminal Procedure Regarding ... Nicolae Silviu PANĂ \& Ana Maria PANĂ

Even if we respect this opinion, we do not share it, given the arguments we will develop further.

For the start, with the risk of being criticized, we will recall some theoretical aspects related to jurisdiction in criminal matters.

\section{General notions regarding jurisdiction in criminal matters and the correlation with the material jurisdiction of the judge of rights and freedoms to judge the proposal of pre-trial detention}

Jurisdiction is the extent to which a judicial body (judge of rights and freedoms, judge of the preliminary chamber or court judge) exercises their power to resolve cases of criminal law, in other words, the extent to which they exercise their jurisdiction. This is also the objective aspect of the concept of criminal jurisdiction, as it derives from the objective need to delimit the sphere of activity in criminal matters for various courts. In this respect, the competence is also enshrined in the criminal procedure codes regulating this delimitation by distributing - according to certain criteria - the criminal cases between various courts. Depending on this legal division, the criminal jurisdiction of a particular court represents the totality of the criminal cases which that court is entitled to try and judge.

In European doctrine, it has been stated that when we speak of jurisdiction, we have in mind the case brought before the judge. Thus, in Italian law, the objective aspect of the concept of jurisdiction is pointed out by Manzini, who writes: "The material jurisdiction is the limited legislative circle within which a judge, having ordinary or special jurisdiction, can exercise jurisdiction".

Our older doctrine retained only this aspect regarding jurisdiction, without attributing any qualification to it. Thus, V. Dongoroz stated: "Positively conceived, objective capacity appears as a power of attorney regarding the framework of procedural acts that a judicial body is obliged to fulfil in the conduct of a judicial process".

In its subjective aspect, jurisdiction is the right that a court has to judge and issue on a certain concretely individualized case, which was brought before the court.

In Italian law, the subjective aspect of jurisdiction is pointed out by V. Manzini, who stated that: "Subjectively, jurisdiction is the power / duty of a judge to exercise his or her own jurisdiction over a particular criminal case", but also by G. Leone, who affirms that: "Subjectively, jurisdiction is the ability of a determined judge to investigate and resolve a case". 
As far as we are concerned, criminal jurisdiction is the ability recognized by law to a court (judge of rights and freedoms, judge of the preliminary chamber or court judge) to rule on requests, proposals, complaints, appeals or any other notices of acts and measures restricting the fundamental rights and freedoms of the person and on the lawfulness of the act of prosecution, of the evidence on which the prosecution is based or on the acts performed during the criminal investigation, and on the legality and validity of the trial, or to try and resolve a particular criminal case. The competence of the judiciary body is an essential element that derives from the principle of legality, a principle that is a component of the rule of law.

Substantive jurisdiction is determined by the object of the criminal case, i.e. by the act committed and provided for by the criminal law, which caused the conflict of criminal law which is the subject of the case brought before either the court or the judge of rights and freedoms, as the case may be (Barbu \& Flaminzeanu, 2018).

Regarding this institution, in our newer criminal doctrine, M. Udroiu writes: "It is the form of jurisdiction determined by the object of the criminal case (the crime that gave rise to the conflict of criminal law) by reporting to which it is established which of the judicial bodies of different degree may prosecute, judge a specific criminal case, namely which is the court in which the judges of rights and freedoms or preliminary chamber operate to rule according to the powers conferred by the Code of Criminal Procedure" (Udroiu, 2016).

Once here, the following clarification must be made (which we consider is likely to clarify the issue under analysis): the judge of rights and freedoms is invested by the prosecutor with a criminal case, and not with the criminal investigation itself, which obviously may include other procedural documents, which are not brought to the attention of the judge of rights and freedoms in the local court. Criminal cases (which are the material object of the trial) are the legal relationship of the conflict, arising from the commission of the crime (the legal object of the criminal trial). A criminal case means all the materials of the trial (in documentary and evidentiary aspect) regarding the commission of a crime or in connection with the resolution of a request addressed to the criminal court.

In the light of the above-mentioned analysis, we wonder what the judge of rights and freedoms will do when the prosecutor, for reasons related to the tactics of the investigation (and not infrequently is this situation encountered in practice), does not mention in the report the aspect that criminal investigation had initially began in rem for deed/deeds that are being tried in merits by the county court or the court of appeal. 
Practical Application of the Provisions of the Code of Criminal Procedure Regarding ... Nicolae Silviu PANĂ \& Ana Maria PANĂ

We also note that the activity of verifying the jurisdiction - in all its aspects is carried out without the court's, in this case the judge of rights and freedoms, possibility to administer evidence for this purpose and even to re-evaluate the acts carried out during the criminal investigation. The judge of rights and freedoms must, in principle, limit himself to the verification which he carries out exclusively on the data contained in the report requesting pre-trial detention.

To all this is added, even as an alternative, but relevant to the clarification of the issue under discussion, the hypothesis that the criminal investigation was conducted for several crimes, and those that establish jurisdiction are those by which the criminal action was initiated and the prosecution may be ordered. Thus, in the event that a defendant has been investigated in a case for the crime of terrorism, under the aspect of which there is insufficient evidence to be able to propose pre-trial detention by the prosecutor, the power to resolve the proposal for pre-trial detention for other related offences (for example, attempted murder, bodily harm, noncompliance with the arms and ammunition regime) belongs to the competent court corresponding to the respective offences - the county court, and not to the court of appeal, which has material jurisdiction only for the crime of terrorism.

A similar situation arises when the indictment provides for the prosecution of a defendant for a crime within the jurisdiction of the county court and for a dismissal of a criminal offence, which is within the jurisdiction of the local court: which court has the jurisdiction to resolve the complaint against the dismissal disposed through the indictment act, according to art. 340 para. 1 of the Criminal Procedure Code (Barbu, 2016d, 2016e).

Acknowledging the findings of the judge of the court of judicial control, it cannot be argued that the judge of rights and freedoms who resolved the requests for the approval of searches or other evidentiary proceedings during the criminal investigation, according to art. 53 letter e of the Criminal Procedure Code, will automatically and always resolve the pre-trial detention proposal, as, according to the legal provisions, this is not a criterion in determining the jurisdiction of the judge of rights and freedoms in resolving the pre-trial detention proposal. The only criterion for determining the material jurisdiction of the judge of rights and freedoms in resolving the proposal for pre-trial detention is that they should be a part of the court which would have jurisdiction to try the case in merits, i.e. the court that has jurisdiction to try the crime that was committed.

In relation to the jurisdiction of the judge of rights and freedoms to resolve requests for the approval of searches during criminal proceedings, the use of special 
methods of surveillance or investigation is determined and at the same time conditioned by the initiation of criminal proceedings (art. 140 et seq. of the Criminal Procedure Code). This is unlike the jurisdiction of the judge of rights and freedoms to resolve the proposal for pre-trial detention when the jurisdiction is determined and established by the initiation of criminal proceedings regarding the commission of an offence by the defendant, according to the provisions of art. 223 with reference to art. 82 of the Criminal Procedure Code.

As a result, the act that attracts the material jurisdiction is the ordinance to initiate criminal proceedings, given that nothing prevents the prosecutor to extend the indictment for other crimes, such as the one provided by art. 367 of the Penal Code, or to establish the existence of one of the cases provided by art. 16 para. 1 of the Criminal Procedure Code.

Or, in the noted case mentioned above, the proposal for pre-trial detention concerns defendants against whom the criminal action was initiated for the crime of disturbing public order and peace and non-compliance with the weapons and ammunition regime, provided by art. 371 and art. 342 of the Penal Code, and the jurisdiction to judge these crimes, according to art. 35 of the Criminal Procedure Code, belongs to the local court, and not to the county court.

\section{Conclusions}

In the present study we tried to harmoniously combine legal research with judicial practice, obviously, without claiming that the above is an exhaustive analysis of the field addressed. The importance of clarifying, even by case law, the issues addressed is necessary in order to clearly understand and apply the will of the legislator in the matter under debate.

\section{References}

Barbu, D. (2016a). Drept procesual penal. Partea generală [Criminal procedural law. The general part]. Lumen.

Barbu, D. (2016b). Aspecte practice privind excepția necompetenței teritoriale în camera preliminară [Aspects of practice with exceptions territorial incompetence in preliminary camera]. Universul Juridic.

Barbu, D. (2016c). Danger to the public order - An essential condition in taking and differentiating preventive measures. In A. Sandu, A. Frunza, T. Ciulei \& L. Gorghiu (Eds.), MEPDEV 2015, Multidimensional Education and Professional Development. Ethical V alues, 12-14 November, 2015 - Targoviste (Romania) (pp. 43-46). Editografica. 
Practical Application of the Provisions of the Code of Criminal Procedure Regarding ... Nicolae Silviu PANĂ \& Ana Maria PANĂ

Barbu, D. (2016d). Some aspects concerning the civil action in the criminal proceeding. In A. Sandu, T. Ciulei \& A. Frunză (Eds.), The European proceedings of social and behavioural sciences, 15 (pp. 95-101). Future Academy. https://doi.org/10.15405/epsbs.2016.09.12

Barbu, D. (2016e). The principle of separation of judicial function. Revista LESIJ, 1. http://lexetscientia.univnt.ro/ro/volume/LESIJ-JS-XXIII--1- -2016 96.html

Barbu, D., \& Flaminzeanu, I. (2018). Discussions on the preliminary chamber from the perspective of article 282 of the Criminal Procedure Code. Valabia University Law Study, XXXI(1), 89-122.

http://www.analefsj.ro/ro/reviste/numarul31/nr31.pdf\#page $=89$

Romanian Parliament. (2009, July 24). Legea nr. 286/2009 privind Codul penal [Law no. 286/2009 regarding the Penal Code]. Monitorul Oficial al României, 510. http://legislatie.just.ro/Public/DetaliiDocumentAfis/109854

Romanian Parliament. (2010, July 15). Lege nr. 135/2010 privind Codul de procedura penala [Law no. 135/2010 regarding the Criminal Procedure Code]. Monitorul Oficial al Romaniei, 486. http://legislatie.just.ro/Public/DetaliiDocumentAfis/120609

Udroiu, M. (2016). Procedură penală. Parte generală. Noul Cod de procedură penală [Criminal procedure. General part. The new Code of Criminal Procedure]. C.H. Beck. 